\title{
Wprowadzenie \\ O przyczynach i specyfice geograficznych badań nad mniejszościami narodowymi i etnicznymi
}

Wraz z demokratyzacją życia w Polsce, zapoczątkowaną reformą ustrojową w 1989 r., nastąpił wyraźny wzrost zainteresowania problematyką tutejszych mniejszości narodowych i etnicznych. Tendencja ta jest o tyle interesująca, że te niegdyś licznie zamieszkujące Rzeczpospolitą społeczności stanowią współcześnie zaledwie niewielką część ludności kraju. Można przyjąć, że ten skromny udział jest, paradoksalnie, jedną z przyczyn zwrócenia uwagi badaczy (choć przecież nie tylko) na tych, którzy w sytuacji daleko posuniętej homogeniczności etnicznej społeczeństwa - stanowiącej o anomalii w historii Polski ostatnich kilkuset lat - zachowali odrębność wyrażaną w kategoriach narodowych (zbieżnych $\mathrm{w}$ wielu przypadkach $\mathrm{z}$ religijnymi), identyfikując się z innym narodem niż dominujący.

Źródłem wzrostu wrażliwości na problemy mniejszości, uruchamiającej często aktywność badawczą, była również potrzeba odreagowania powojennej polityki władz państwowych, które, dążąc do budowy jednolitego narodowościowo i wolnego od wpływów religii społeczeństwa, rugowały tematykę dotyczącą tych grup z wszelkich obszarów życia publicznego (nikły odsetek osób o niepolskich identyfikacjach działania obozu rządzącego tylko ułatwiał). Prowadziło to na ogół do fałszywych przeświadczeń, że mniejszości narodowe w Polsce stanowią już jedynie kategorię historyczną i z takiej perspektywy powinny być postrzegane. Przemiany ustrojowe uzmysłowiły, że śladowo dotąd obecny w dyskursie publicznym i badaniach naukowych temat państwa wielu narodów (i wyznań) nie musi być zamknięty w - szerokiej wszakże, ale nieodzwierciedlającej rzeczywistości - formule przeszłości. Warunkowana ustrojem politycznym tabuizacja zaczęła więc ustępować miejsca zainteresowaniu różnorodnością etniczną Polski.

Znamienne, że od końca lat 80. ubiegłego wieku, na fali demokratycznych przemian, można zaobserwować również proces emancypacji mniejszości narodowych i etnicznych w Polsce. Wolność wyboru stwarza bowiem nowe podłoże dla identyfikacji z niepolską lub nie tylko polską tradycją narodową. Odkrywane przez siebie i zaistniałe w świadomości (jako ważny element własnej osobo- 
wości) poczucie odrębności w stosunku do polskiej większości staje się źródłem niewielkiego wzrostu liczebnego niemal wszystkich grup mniejszościowych, choć w odniesieniu do każdej z nich przebiega on inaczej (warto podkreślić, że do wszelkich danych z dziedziny statystyki narodowościowej należy podchodzić z wyczuciem i daleko posuniętą ostrożnością, ponieważ dotyka ona kwestii niezmiernie subtelnych i trudno mierzalnych, determinowanych nie tylko czynnikami etnicznymi). Samoidentyfikacja narodowościowa podlega nierzadko transmisji w kierunku różnorodnych, nieskrępowanych inicjatyw środowiskowych. Pielęgnowaniu i odkrywaniu tożsamości sprzyja również zainteresowanie innością, wielopostaciowością współczesnego świata, w którym - w jakimś stopniu w odpowiedzi na postępującą globalizację, a wraz z nią unifikację kulturową społeczeństw - wzmagają się procesy polegające na odradzaniu się różnych typów tożsamości (narodowej, etnicznej, religijnej, językowej).

Szeroko rozumianym mniejszościom narodowym i etnicznym w Polsce oraz w wybranych państwach świata (w Izraelu, Kolumbii, Peru i Rosji) poświęcony jest niniejszy tom. Jego autorami są badacze reprezentujący takie dziedziny nauki, jak: historia, socjologia, antropologia i geografia. Zastosowanie właściwego dla danej specjalności aparatu naukowego nie wykluczyło w przypadku niemal każdego z nich spojrzenia interdyscyplinarnego. Wydaje się to oczywiste, bowiem nawet dwie ,tytułowe” geografie: historyczna i polityczna - choć reprezentowane najliczniej, to pozostające przecież tylko częściami uznanych tradycyjnie dziedzin wiedzy - funkcjonują na pograniczu nauk.

Niezależnie od spojrzenia metodologicznego dociekania autorów koncentrowały się na związkach zachodzących między mniejszościami a przestrzenią, interakcjami o charakterze przestrzennym pomiędzy tymi grupami oraz między nimi a większością. Według klucza przestrzennego porządkowano różne aspekty życia osób skupionych w małych liczebnie wspólnotach, występujących często w nierównoprawnych relacjach z grupą większościową, a w związku z tym zepchniętych na margines życia społecznego w państwach lub regionach zamieszkania, zobligowanych do zajmowania tych, a nie innych miejsc w przestrzeni $i$ organizowania ich w sposób nie zawsze zgodny $z$ własnymi potrzebami.

$\mathrm{W}$ tomie zaprezentowano nie tylko wiele interesujących informacji i danych na temat grup mniejszościowych w wybranych państwach, ale także kontrowersje, a nawet spory odnoszące się do kryteriów zaliczenia danej społeczności w poczet uznanych prawnie mniejszości (narodowych, etnicznych) oraz obecności tych ostatnich w przestrzeni publicznej. Analizą objęto - rzadko spotykany na łamach publikacji geograficznych - problem dyskryminacji z powodów rasowych oraz przynależności do zajmującej niższy status społeczny rdzennej ludności. Kwestie fizycznych prześladowań i aktów terroru wobec wybranych 
grup ludności rozpatrywano zarówno pod kątem współczesności, jak i historycznym. W tym drugim przypadku przedstawiono nie tylko zbiorowe, brutalne akty przemocy skierowane wobec mniejszości narodowych (w dużym stopniu również religijnych) w Polsce tuż po wojnie, ale i odpowiedź na nie w postaci organizacji paramilitarnych rekrutujących przedstawicieli jednej z takich społeczności, a także współczesne dążenia do odkrywania prawdy historycznej o upośledzonej pozycji mniejszości $\mathrm{w}$ okresie międzywojennym oraz nietolerancji i terrorze wywodzących się z tradycji powojennego podziemia antykomunistycznego.

Z kolei o pozytywnych efektach wynikających ze spotkań przedstawicieli wielu kultur, podczas których dochodziło nie tylko do uzupełniania w danym miejscu „walorów” reprezentowanych przez każdą z nich, ale i twórczego ich funkcjonowania w postaci stworzenia wyjątkowego kanonu badań naukowych, informują rozważania poświęcone rozwojowi geografii w wieloetnicznym ośrodku miejskim.

Obok wartości naukowej, wyrażonej m.in. staraniami o zachowanie obiektywizmu wobec rozpatrywanych zagadnień, zawarte w tomie artykuły zawierają pewien ładunek emocji. Dostarczają sposobności wczucia się w świat przeżyć przedstawicieli grup poddawanych dyskryminacji - przez co oprócz poznawczego i edukacyjnego można dostrzec w wielu tekstach walor terapeutyczny spychanych na margines życia społecznego, które są lub były nieodłączną częścią wielu państw, regionów, miast i wsi, twórczo w nich funkcjonowały, a które, nie z własnej na ogół winy, stały się w tych miejscach nieobecne lub znalazły $\mathrm{w}$ znikomej mniejszości. A przecież grupy te, trawestując słowa Andrzeja Mencwela, historyka i krytyka literatury, powodują, że tworzy się „pluralistyczne, wieloziarniste społeczeństwo, a nie mglista, jeśli nie mazista «wspólnota narodowa». Ziarna, z których składa się taki organizm, są różne - społecznie, wyznaniowo, etnicznie, regionalnie - ale całość jest mocna, trwała i odporna"1.

Andrzej Rykała

\footnotetext{
1 „Ale Historia”, Tygodnik Historyczny - dodatek do „Gazety Wyborczej”, z 1 lutego 2016 r., s. 15.
} 